(2) Open Access Full Text Article

\title{
Improving patient satisfaction in glaucoma care
}

This article was published in the following Dove Press journal:

Clinical Ophthalmology

\section{Samsul Islam \\ Ahmad Salha \\ Saeed Azizi}

Faculty of Medicine, St George's Hospital Medical School, London, UK
Correspondence: Samsul Islam Faculty of Medicine, St George's Hospital Medical School, Cranmer Terrace, London SWI 7 ORE, UK

Tel +44 798520 I878

Email samsulislam_1997@hotmail.co.uk

\section{Dear editor}

We read the article by Foo et $\mathrm{al}^{1}$ with great interest. We were intrigued by the factors influencing satisfaction rates among glaucoma patients. It made us question what changes could be made in the future attempting to improve patient satisfaction.

Similar to Foo et al, ${ }^{1}$ we were also surprised to find a lower end-point intraocular pressure was linked with increased patient dissatisfaction. As stated by Foo et al, ${ }^{1}$ other studies exploring clinical outcomes and patient satisfaction found that a positive clinical state was linked to higher patient satisfaction. Prakash ${ }^{2}$ proposes a three-way association between patient satisfaction, increased compliance, and better clinical outcomes. Hence, in attempting to investigate patient satisfaction, it would be appropriate to assess patient compliance and clinical outcomes.

Robin and Grover ${ }^{3}$ identified three key factors in improving compliance in glaucoma patients. These factors include patients understanding what glaucoma is, a clear reasoning behind their treatment, and a simplified treatment regimen. A novel method to improve compliance and satisfaction rates among glaucoma patients is implementing patient education programs. Patient education programs have been shown to be effective. Stenberg et $\mathrm{al}^{4}$ carried out a systematic review of patient education programs and identified their potential in improving patient compliance and satisfaction. Based on the results of Foo et al, ${ }^{1}$ the key areas which should be addressed in the patient education programs are those found to be strongly linked to patient dissatisfaction. These areas include explanation of glaucoma test results, explanation of the complications of poorly controlled glaucoma, and advice on managing glaucoma. We further propose the education programs should incorporate limitations with health care services in order to appropriately manage the expectations of patients.

Foo et $\mathrm{al}^{1}$ suggested private patients were less dissatisfied overall due to longer consultation times and more personalized consultations. A meta-analysis of primary care consultations suggested it is not the length of time spent in a consultation but rather attempting to explore and find psychosocial factors that causes an increase in patient satisfaction. ${ }^{5}$ Thus, we feel that it is the structure and approach of the consultation which should be targeted instead of primarily focussing on increasing the length of the consultation. This will aid health care providers who are time restricted due to increasing patient numbers.

Tackling the factors affecting glaucoma patients' satisfaction can be approached from different avenues. Assessing patient compliance, providing education programs, and changing the structure of consultations are concepts that may positively influence patient satisfaction. 


\section{Disclosure}

The authors report no conflicts of interest in this communication.

\section{References}

1. Foo VHX, Tan SEM, Chen DZ, et al. Areas and factors associated with patients' dissatisfaction with glaucoma care. Clin Ophthalmol. 2017; 11:1849-1857.

2. Prakash B. Patient satisfaction. J Cutan Aesthet Surg. 2010;3(3): $151-155$.
3. Robin A, Grover DS. Compliance and adherence in glaucoma management. Indian J Ophthalmol. 2011;59(Suppl 1):S93-S96.

4. Stenberg U, Haaland-Øverby M, Fredriksen K, Westermann KF, Kvisvik T. A scoping review of the literature on benefits and challenges of participating in patient education programs aimed at promoting self-management for people living with chronic illness. Patient Educ Couns. 2016;99(11):1759-1771.

5. Lemon TI, Smith RH. Consultation content not consultation length improves patient satisfaction. J Family Med Prim Care. 2014;3(4): 333-339.

Dove Medical Press encourages responsible, free and frank academic debate. The content of the Clinical Ophthalmology 'letters to the editor' section does not necessarily represent the views of Dove Medical Press, its officers, agents, employees, related entities or the Clinical Ophthalmology editors. While all reasonable steps have been taken to confirm the content of each letter, Dove Medical Press accepts no liability in respect of the content of any letter, nor is it responsible for the content and accuracy of any letter to the editor.

\section{Publish your work in this journal}

Clinical Ophthalmology is an international, peer-reviewed journal covering all subspecialties within ophthalmology. Key topics include: Optometry; Visual science; Pharmacology and drug therapy in eye diseases; Basic Sciences; Primary and Secondary eye care; Patient Safety and Quality of Care Improvements. This journal is indexed on

\footnotetext{
Submit your manuscript here: http://www.dovepress.com/clinical-ophthalmology-journal
}

\section{Dovepress}

PubMed Central and CAS, and is the official journal of The Society of Clinical Ophthalmology (SCO). The manuscript management system is completely online and includes a very quick and fair peer-review system, which is all easy to use. Visit http://www.dovepress.com/ testimonials.php to read real quotes from published authors. 